This item was submitted to Loughborough's Research Repository by the author.

Items in Figshare are protected by copyright, with all rights reserved, unless otherwise indicated.

\title{
Kurt Lewin's leadership studies and his legacy to social psychology: is there nothing as practical as a good theory?
}

\section{PLEASE CITE THE PUBLISHED VERSION}

http://dx.doi.org/10.1111/jtsb.12074

\section{PUBLISHER}

(C) John Wiley \& Sons Ltd

\section{VERSION}

AM (Accepted Manuscript)

\section{PUBLISHER STATEMENT}

This work is made available according to the conditions of the Creative Commons Attribution-NonCommercialNoDerivatives 4.0 International (CC BY-NC-ND 4.0) licence. Full details of this licence are available at: https://creativecommons.org/licenses/by-nc-nd/4.0/

\section{LICENCE}

CC BY-NC-ND 4.0

\section{REPOSITORY RECORD}

Billig, Michael. 2019. "Kurt Lewin's Leadership Studies and His Legacy to Social Psychology: Is There Nothing as Practical as a Good Theory?". figshare. https://hdl.handle.net/2134/16182. 
Kurt Lewin’s leadership studies and his legacy to social psychology: Is there nothing as practical as a good theory?

Michael Billig

Department of Social Sciences

Loughborough University 


\section{Abstract}

This paper re-examines Kurt Lewin’s classic leadership studies, using them as a concrete example to explore his wider legacy to social psychology. Lewin distinguished between advanced “Galileian” science, which was based on analysing particular examples, and backward “Aristotelian” science, which used statistical analyses. Close examination of the way Lewin wrote about the leadership studies reveals that he used the sort of binary, valueladen concepts that he criticised as “Aristotelian”. Such concepts, especially those of "democracy" and "autocracy", affected the way that he analysed the results and the ways that later social scientists have understood, and misunderstood, the studies. It is argued that Lewin's famous motto - "there is nothing as practical as a good theory" - is too simple to fit the tensions between the leadership studies and his own views of what counts as good theory.

Key words: Kurt Lewin; leadership studies; democracy and autocracy; social psychology; Aristotelian science; good theory 
Kurt Lewin is often depicted as a mythic figure in the history of social psychology: the textbooks typically describe him as the founding father of experimental social psychology, a genius whose life was tragically cut short. Like many mythic figures, Lewin symbolically seems to unite contradictory elements. His famous motto - "there is nothing as practical as a good theory” - appears to unite theory and practice within the orbit of experimental methodology. When social psychologists quote the motto, as they regularly do, it is as if Lewin had demonstrated the essential harmony between theory, practice and experimental methodology. Rather than taking the myths and the motto at face value, the present study examines contradictions within Lewin's work, as well as contradictions between his work and the later mythology. It does so by re-examining Lewin’s classic study on leadership, which has been described as the most widely cited study in the history of leadership research and “the benchmark” study of its time (Ledlow and Coppola, 2011, p. 62). Lewin’s leadership study will be specifically re-examined in the light of Lewin’s ideas about what constitutes a good theory. It will be argued that the study diverged in significant ways from Lewin's own philosophy about the practice of good research and the formulation of good theory.

The initial leadership study was conducted in 1938 at Iowa University by Ronald Lippitt, a graduate student supervised by Kurt Lewin. Two groups of eleven year-old children, mainly boys, participated after school in mask-making groups, meeting over a number of weeks. With one group, Lippitt acted as a "democratic" leader while with the other he acted as an "authoritarian" leader. There were trained observers noting how the children behaved in the various group sessions. Lewin and Lippitt (1938) reported the initial results and Lippitt (1940) wrote up the findings in detail. Ralph White joined Lippitt to run the second experiment also under Lewin's direction. They used the same basic procedure but in a 
more complex design. This time, there were four groups (all boys) and four different leaders, as well as a third leadership style - the laissez-faire style. Each group experienced more than one leader and more than one leadership style. Lewin, Lippitt and White (1999/1939) combined the results from the two experiments. The combined results were also reported by Lippitt and White (1958), while White and Lippitt (1960) in their book Autocracy and Democracy discussed in greater detail and with less formality the conduct, history and findings of both experiments. Lewin frequently referred to the results of the studies in his technical writings (e.g., Lewin, 1946/1997 and 1947/1997) and in his writings addressed to non-specialists (Lewin, 1948, chapters three and five).

Recently a number of social psychologists have been re-examining classic experimental studies in social psychology. Reicher and Haslam (2011) have referred to the "shock of the old", because those, who are re-examining the classics, are overturning long accepted views (e.g., Cherry, 1995; Gibson, 2013; Manning, Levine and Collins, 2007; Perry, 2013; Reicher and Haslam, 2006; Russell, 2011; Smith and Haslam, 2012). Some like Gibson (2013) and Perry (2013) are using archival sources to suggest that what "really” happened was rather different what the original authors said had happened. Others are using current theories of social behaviour, rather than archival sources, to overturn classic interpretations. For instance, Haslam and Reicher (2012) argue that if one applies modern ideas about leadership and social identity to the famous Stanford prison experiment, then there are good reasons for doubting Zimbardo’s interpretations of his results.

This present re-examination of Lewin’s leadership study resembles these revisionist studies because it will suggest that some of Lewin's descriptions of the study, as well as many later accounts, inadequately depict what occurred. It will also be argued that Lewin's interpretations often lacked the subtlety that one would expect from modern analyses of talk and discourse. However, the primary aim is not to re-visit this classic study as an end in itself 
in order to put the historical record right. There is the wider aim of examining the discrepancy between Lewin’s research philosophy and his research practice - a discrepancy that is regularly overlooked by those who mythologize Lewin.

This means taking seriously Lewin's philosophy of science, especially his distinction between Aristotelian and Galileian science which he took from his teacher, the philosopher Ernst Cassirer. It is appropriate to take Lewin's philosophy seriously because he was not the sort of experimental psychologist who is quick to dismiss the demands of philosophy. His biographer and friend Alfred Marrow quoted Kurt's second wife, Gertrud, as saying that Lewin “never abandoned philosophy” (Marrow, 1969, p. 17). The problem is the contradiction between his philosophy and his research. Lewin might have philosophically equated good theory with Galileian science, but his own research practice remained obstinately stuck in the sort of Aristotelian mode that he considered to be scientifically unsatisfactory.

This will be illustrated by considering the leadership studies as a case history of Lewin’s research practices. This is appropriate because, as will be seen, Lewin recommended that social scientists should explore single cases in detail, rather than collect repeated examples. Indeed, Lewin's methodological views might surprise those experimental social psychologists, who consider him to be the founding father of their discipline and who assume that he must have championed the sorts of experimental methods that have become dominant within the discipline. Lewin’s views on methodology might also surprise some critical psychologists, who also assume that he must have been a conventional experimentalist. However, according to Kurt Danziger (1994), Lewin’s methodological legacy remains “something of a buried treasure” (p. 178). 
Lewin's views on methodology were not based on personal preference, as if he enjoyed doing one type of research more than another. His views on methodology were part of his wider philosophy, and followed from his distinction between Galileian and Aristotelian science. So were his views about the sorts of concepts that psychologists should be using and those that they should avoid. As we shall see, Lewin distinguished between Aristotelian and Galileian concepts. In examining the leadership study, it will be argued that Lewin, by his choice and use of concepts, wrote in ways that were at variance with his Galileian ideals.

The intention is not merely to point out these contradictions, but also to examine more generally Lewin's use of language in the conduct of the leadership studies. In particular, the paper critically explores how Lewin's choice of concepts, especially the key terms “democratic" and "autocratic", affected the way that he and his collaborators understood, analysed and presented their results. In doing this, the paper offers a rhetorical analysis of the language used by Lewin and his co-workers. In this context the notion of "rhetoric" refers to the use of persuasive language. Since academic writers seek to persuade their readers, it is inevitable that they use rhetorical language, although they might not be aware of the implications of their own writing practices. Accordingly the critical study of academic discourse, and especially rhetorical conventions, should be considered as important as the analysis of theory and methodology in the social sciences (Billig, 2011 and 2013; Hyland, 2009; Nelson, Megill and McCloskey, 1987). This is why the present paper focuses on examining the language and rhetorical strategies that Lewin and his co-workers used to describe and explain their results, rather than seeking to compare those descriptions and explanations with archival information.

Inevitably this emphasis upon analysing rhetoric involves an approach which differs from Lewin's. The sort of "good” theory that Lewin advocated was designed to reveal the psychological forces that supposedly lay behind linguistic behaviour; he was less concerned 
with systematically analysing how people actually use language in their social world. Lewin's own Galileian approach, it will be suggested, was not well-suited for examining the discursive behaviour of the participants in the leadership studies; nor was it conducive to producing the sort of self-critical analyses that Lewin himself advocated in theory but did not fulfil, at least in relation to his own rhetorical practices. If the end result of this analytic strategy is that the leadership studies and the rhetorical practices of their authors are criticised, then it should be emphasised that the present intention is not to dismiss Lewin and his contribution to the social sciences. Rather, the wider aim is to rescue his work from the sort of uncritical mythologizing that currently surrounds it.

\section{Aristotelian and Galileian Science}

If Lewin believed that a good theory was inherently practical, then throughout his career he sought to distinguish what marked good psychological theory from second-rate theory. At the heart of Lewin’s thinking about science was Cassirer's distinction between out-dated Aristotelian science and advanced Galileian science (Lewin, 1931/1999, 1947/1997 and 1949/1999; Ash, 1998, chapter sixteen; see also Hammersley, 2010, for a valuable discussion of the distinction between Galileian and Aristotelian science in relation to induction and the social sciences). Lewin believed that the psychology of his time was, in the main, stuck in the Aristotelian stage. It may surprise many social psychologists today to discover that some of the characteristics, which Lewin identified as typifying backward Aristotelian psychology, are those which predominate in modern experimental social psychology. Equally, it may surprise students of Cassirer’s work that Lewin ignored Cassirer’s writings on psychology, where the great philosopher, citing Gestaltist ideas, stressed the importance of seeing humans as symbol-using and symbol-creating beings (e.g. Cassirer, 1944/1962; see also Cassirer, 
1999, and Carini, 1973). Lewin was aware that in drawing upon Cassirer, he was avoiding Cassirer’s “treatment of specific problems of psychology” (Lewin (1949/1999, p. 23). Consequently, Lewin used a very much reduced version of Cassirer’s philosophy. He took Cassirer’s idealized image of physics, based on Galileo's work and the possibility of producing mathematical laws, as an ideal for all sciences, including the human sciences. This meant ignoring Cassirer’s arguments that a different sort of understanding was required for human and psychological sciences - an understanding, which cannot be mathematized and which Cassirer in The Philosophy of the Enlightenment (1932/1951) linked to Diderot and the third earl of Shaftesbury (see Billig, 2008, for an appreciation of Shaftesbury's dialogical view of the mind and its potential importance for critical psychologists).

Lewin, in distinguishing between Aristotelian and Galileian sciences, argued for the superiority of the latter over the former. He claimed that Aristotelian science was probabilistic and was based on statistical generalities, not on exact laws. In fact, Lewin decried the use of statistics in psychology. He argued that psychologists and other social scientists should study in detail "concrete, individual cases” from which general laws could be derived (1938a, p. 285). In an article written jointly with his long-term friend, the notable Marxist theorist Karl Korsch, Lewin suggested that the prerequisite for the new sort of scientific psychological and sociological investigation was that "the individual event” needed to be considered “in its particular setting” (Lewin and Korsch, 1939, p. 401). Regarding psychological experiments this meant abandoning the usual procedure of collecting numerous instances of experimental conditions and then statistically comparing the mean scores of the subjects in the different conditions. According to Lewin (1938a), if one seriously seeks to understand the concrete individual case, then "the results of individual experiments cannot be submitted to statistical treatment where the assumption prevails that preceding and succeeding trials are identical in kind”; instead, “each trial must be treated as a separate, 
concrete event, i.e. in an essentially non-statistical way” (p. 284, emphasis in original). This principle applied both to experimental studies of individuals and of groups, as well as broader sociological studies.

Good theory, then, was not to be based upon statistically analysed results from experimental samples, but on the detailed study of particular cases. It was, in Lewin's view, important to understand the underlying forces behind outward behaviour. To comply with the principles of Galileian science, such forces should be expressed in mathematical terms and, in consequence, psychologists should use mathematics to express qualitative, not quantitative, differences (1944/1997). Lewin believed that field theory succeeded in formulating topological formulae to represent the forces in a person’s situation, or life space, which led them to behave as they did (Lewin, 1936 and 1938b). The methodological implication was clear: an experiment, involving the detailed study of a single concrete case, was more valuable than one permitting large amounts of data to be gathered from quickly and superficially studied participants.

Lewin argued that Galileian and Aristotelian sciences not only used different methods but they used different concepts. In Lewin's view, Aristotelian concepts were marked by two characteristics: they had a "valuative character" and they were binary (1931/1999, p. 38). Lewin suggested that most psychologists used "anthropomorphic” or Aristotelian concepts that expressed values, such as the value-laden concepts "normal” and "pathological” behaviour which clinical psychologists use (pp. 38-9). Concepts such as “normal” and “pathological” were also binary since they represented “paired opposites”, unlike Galileian concepts that expressed “continuous gradations” (p. 39). By using neutral, non-binary concepts such as “forces” and “vectors”, Lewin believed that field theory represented an advance over ordinary value judgement. Generally, Lewin disparaged psychologists for using 
the binary, value-laden of everyday language. If psychologists were to use ordinary language concepts, then they should redefine them in specialist, technical ways (1944/1997, p. 192).

This contrast between "good” Galileian and "bad” Aristotelian concepts leads to a problem between the demands of producing good theory and being practical. To be good theorists, psychologists needed to write in technical ways, using concepts that non-specialists would have difficulty grasping. However, to be practically useful, psychologists must be able to communicate with non-specialist audiences. Throughout his career Lewin sought to communicate with wider audiences, from his early article on applied psychology published in Korsch’s Marxist journal Praktischer Sozialismus (Practical Socialism) to his final writings addressed to educational and Jewish community leaders (Lewin, 1921/1999 and 1948, especially Part III; see also John, Eckardt and Hiebsch, 1989). The leadership studies were caught within this continuing dilemma between good and practical science.

\section{Using Aristotelian concepts in the leadership studies: the independent variables}

Lewin and his co-workers labelled the two main independent variables of the leadership studies with ordinary language concepts that were binary opposites: “democracy” and “autocracy”. Inevitably, these terms are inherently political and value-laden. Lewin was, of course, a refugee from an anti-democratic, autocratic regime and his writings about social conflict reflected his deep concern with the dangers of fascism and the need to establish democratic principles in practice (Lewin, 1948). He argued that the leadership studies carried wider social messages about political culture and leadership (Lewin, 1948, chapters three and five). 
In their research reports Lewin and his team, used "democracy”, “democratic atmosphere” and “democratic style of leadership” interchangeably, as they did “authoritarian” and "autocratic”. These terms rested on the value-laden contrast between autocracy/authoritarianism and democracy. Moreover, by using “democracy” interchangeably with terms such as "democratic atmosphere” and "democratic style of leadership” they were assuming that the democratic atmospheres and styles, that they were observing, were actually democratic, rather than being democratic appearances that hid non-democratic realities. In the second experiment, Lewin and his co-workers introduced the concept of "laissez-faire" and, as we shall see, they did this to preserve the basic ideological values of the study.

White and Lippitt (1960) wrote that early in their discussions of the leadership roles, they found themselves using ordinary language terms to describe these roles. Rather than calling them "role one”, "role two" and "role three”, as might have been scientifically correct, it seemed "natural and appropriate to us" to give them the names "autocratic", "democratic" and "laissez-faire" (p. 10). The comment is interesting. It shows the extent to which the researchers took their everyday understandings and values into the research programme, rather than deriving their key concepts from psychological theories. It also indicates the ideological nature of their everyday assumptions. Some researchers claim that "ideology" represents the processes by which people come to accept their social world as being "natural”. If the researchers considered it "natural” to use political terms such as "autocratic" and "democratic" (and we will see that "laissez-faire" has a different history within the research project), then the researchers, in acting as researchers, were themselves engaged in ideological actions in the sense that they were accepting conventional political language as being "natural”.

Lewin and Korsch (1939) stressed that when social psychologists seek to study group processes, they must take account of “the existing 'ideologies' of the groups concerned” (p. 
401). The group leaders were in what Lewin (1938b) termed an "overlapping situation”: they were simultaneously part of the life of the groups by virtue of their roles as leaders, and also they were acting as researchers, belonging to the group of researchers. Lewin and Korsch’s dictum should require them to be self-analytical about their own existing ideologies and about the possible effects of those ideologies on their behaviour as both group leaders and researchers. This would mean critically examining their use of terminology such as “democracy” and "autocracy”, let alone "democratic atmosphere” or "style”.

Instead, the researchers tend to take for granted - or treat as "natural" - that the phenomena which they were studying should be called “democracy” and “autocracy”. The way that the researchers operationalised these concepts has been criticised and it is not intended to discuss these criticisms here (see Gastil, 1994). The researchers used understandable guidelines. For instance, in autocratic groups the leader "usually dictated the particular work task and work companions of each member" while in democratic groups "the members were free to work with whomever they chose and the division of tasks was left up to the group"; in autocratic groups "all determination of policy" was by the leader, while in the democratic groups all policies were "a matter of group discussion and decision” (Lewin et al, 1939/1999, p. 229).

In practice matters were not quite so clear-cut. The policy to have a leader and to make masks was not decided democratically in the democratic groups, nor was the actual democratic leader chosen by the group members. The leaders in the democratic groups would typically decide which matters were for discussion and group decision and which were not. If this was a "democracy”, it was a very limited democracy, for power firmly resided in the hands of the adult leaders, who controlled what decisions were to be delegated to the group members. Indeed, many school teachers nowadays involve children in classroom discussions, rather than issuing outright commends, but that does not mean that their classrooms should be 
called “democracies” for the teachers retain power even if they exercise this power subtly (Edwards and Mercer, 1987).

Above all, the leaders were responsible for running the experiment. They had to ensure that they created recognizably "democratic” and "authoritarian” conditions. This led to a paradox: sometimes democratic leaders were more controlling than authoritarian leaders when they sought to control what they considered to be undemocratic behaviour. In one episode the leader is trying to ensure open discussion but one of the boys is struggling to be heard. The leader, using the "democratic style" of command, in which "we" is used to indicate "you”, says: "We ought to listen to what Hamil has to say and take our turns" (White and Lippitt, 1960, p. 102). The leader here is telling the children how to behave.

By contrast, the autocratic leaders could not be too autocratic, because, in order to be successful experimenters, they had to permit the children to behave freely. Autocratic leaders might issue orders, but they could not insist upon those orders being obeyed, without the risk of affecting the experimental results. Given that "autocracy” was the "bad” independent variable, as contrasted with the "good" variable of democracy, it was in the interests of the experimenters to let the participants behave badly in the autocratic groups. Lippitt (1940) reports on the children yelling hysterically and ignoring the autocratic leader, who displays “exaggerated patience” and merely stares at the offenders without saying anything (p. 86). Moreover, the autocratic leaders possessed no punitive powers. Unlike even the mildest of teachers, these autocrats could not discipline the children. At most they could have excluded recalcitrant children from the group, but this would have threatened the experimental design. In short, they were autocrats without autocratic powers.

The researchers in their various reports reproduce some of the observers' notes but they do not analyse particular episodes, or interactions, in any concrete detail. A modern 
discursive psychologist might pay close attention to particular episodes, analysing how the participants interacted and used language. In doing this, they would be fulfilling Lewin's demand to analyse concrete particulars. Moreover, they would be taking a critical stance towards the use of the terms "autocratic" and "democratic". Instead of accepting these terms at face value, the analyst would be examining how in practice an autocratic leader or democratic leader actually exercised powers of leadership in their interactions within the groups and how they used the terms "autocratic" and "democratic" in conversations with fellow researchers.

Lewin advocated a critical stance: we should treat scientists, he suggested, in the same way as we treat government - with "a great deal of distrust and an eternal vigilance against an overextension of power” (1943/1999, p. 336). Lewin (1943/1999) suggested that psychologists, when trying to understand utterances, need to look beyond grammatical form to the "social meaning" of utterances. For example if a teacher or nazi said "Would you close the door?” they would be uttering a command, rather than asking a question. In trying to be “objective”, most psychologists, according to Lewin, would typically ignore the "social meaning” of such an utterance and would classify it as a question purely on the basis of its grammatical form (p. 340).

It is arguable whether the researchers in the leadership study followed this critical stance fully, which looks beyond the grammatical form of an utterance to its social function. Lippitt (1940) and White and Lippitt (1960) gave examples of democratic leaders supposedly opening up decisions for democratic discussion rather than giving orders. Many of the examples were of the type: “'Would you like me to give you a little idea of how they generally make masks?’ (All nod)” (Lippitt, 1940 p. 77); or “Don’t you think it would be a good idea if we tackled one at a time?” (p. 111). These directed questions resemble those that Edwards and Mercer (1987) discovered liberal teachers using as a means of exercising 
control without explicitly giving orders. These questions contain what conversation analysts have called a "preference structure” for agreement, such that agreement is invited and disagreement can be problematic (Pomerantz, 1984; Lerner, 1996). The leader, in effect, was inviting the children to agree - to "nod" is easy but to disagree is more complicated and potentially awkward. Disagreeing would have put the child in a position where they would have had to justify their disagreement and thereby expose themselves to criticism from the adult leader. Lewin and his collaborators did not view these "questions" as means by which leaders can exert social control, but viewed them as genuine questions, asked in a democratic spirit. Of course, Lewin should not be criticised for failing to anticipate later investigations into conversational meaning, but he can be criticised for being partial in his critique. He warned against taking authoritarian autocrats at their grammatical word, whilst uncritically accepting similar forms of wording from "democratic" authorities. It was as if the category “democratic” offered protection from criticism.

\section{Using Aristotelian terminology: the origins of "laissez-faire"}

Anyone reading Lewin et al (1939/1999) would get the impression that the researchers intended from the outset that the second experiment should have an extra condition - laissezfaire leadership. The authors followed the convention of report-writing by using the passive voice when describing the procedures of the second experiment: "Four new clubs of 10-yearold boys were organized...the variety of clubs was extended...To the variable of authoritarian and democratic procedures was added a third, 'laissez-faire”' (p. 227, italics in original; see Biber and Conrad, 2009; Billig, 2011 and 2013; Billig and Marinho, in press, for discussions of the use of the passive voice in methods sections). The phrasing conveys that the order of events followed the structure of the research report: the idea for the design preceded the 
running of the experiment, which preceded the collection of data, which preceded the analysis (Swales, 2006). But this was not so.

We are fortunate to have three further, less formal accounts of the second experiment and its history: the book by White and Lippitt (1960), Miriam Lewin’s memoir of her father (M. Lewin 1998) and Marrow’s (1969) biography of Lewin. Apparently the experimenters initially decided that the second study, like the first, would compare democratic and authoritarian styles of leadership. They soon became aware that the children in White's group were not behaving as expected in the democratic condition: the atmosphere of the group "had become so anarchic, and the leader so generally ignored” that the group was not functioning as “a well-integrated democracy” (White and Lippitt, 1960, p. 110).

The group - the Charlie Chan Group - seemed to have more than its fair share of boys, whom Lippitt and White found problematic. According to the researchers, the group contained "three outstanding trouble makers", including one boy who was "more definitely a disciplinary problem” than any of the other boys in the whole study (White and Lippitt, 1960, p. 107). According to White and Lippitt (1960), the two most disrespectful boys of the Charlie Chan group “made democracy harder to achieve” and were "a net liability from the standpoint of democracy” (p. 174).

The problem was not that these boys were anti-democratic but in one sense they were too democratic. These difficult boys did not treat adults with respect but treated them "as equals” showing “indifference to adult-sponsored values” (Lippitt and White, 1958, p. 509). White and Lippitt (1960) gave an example of 'Reilly', the most problematic boy, interrupting and contradicting the leader, "talking to him as a peer" (p. 107). Lippitt and White did not appreciate being treated like this. Their dislike is clear, especially their dislike of 'Reilly' (Lippitt and White, 1958, pp. 508f; White and Lippitt, 1960, pp. 175f). In the autocratic 
condition, Reilly led an outright rebellion, mobilizing the other boys into a strike. The researchers did not go into details about the episode, which, if successful, would have threatened the design of the experiment but would have provided a concrete example of how autocracy could be resisted.

Lippitt and White (1958) dismissed Reilly’s capabilities as a leader, claiming “he was not actually a leader in the sense that he showed any planning or organizing ability”; he was only a leader in that his "headlong, self-centred activity was imitated by others in the group" and he was successful in getting "gullible” boys to accept him "at his own valuation” (pp. 508-9). Lewin et al (1939/1999) report that the rebellion failed when the boys’ courage “seemed to wane” (p. 241). In all such comments, the ideology of the researchers is clear: they were not favouring rebellion against authority in this situation, and disapproved of the boys treating the adult leaders with too much equality. When this occurred, the researchers considered that democracy was being threatened.

Lippitt and White feared that the behaviour of this group in the democratic condition was threatening the success of the experiment, because democracy did not seem to be emerging well. Apparently Lewin saved the day. He suggested that White had been allowing the boys too much freedom and that his leadership should not be called "democratic" but "laissez-faire”. The team decided to build White’s style into the experimental design by running further laissez-faire groups. This story of looming disaster and rescue by the "laissezfaire" label does not appear in the journal reports. Nor did Lewin mention the story in his various summaries of the second experiment (e.g., Lewin, 1948, chapters three and five). The official version has become part of disciplinary folklore, with the textbooks presenting the laissez-faire condition as if it had been planned in advance (e.g., Hergenhahn and Henley, 2013, p. 459; Nelson and Quick, 2011, p. 434). 
Whatever the methodological proprieties of such relabeling, we can ask about the rhetorical consequences of creating a new condition in this way. Basically, Lewin’s rhetorical switch served to protect the reputation of "democracy”. Bad results accruing to "democracy" would have created an ideological problem. Lewin’s solution was Aristotelian, not Galileian, for he did not treat "democratic leadership” as if were a continuous, rather than a binary, concept. For example, he might have classified White’s style of “democratic leadership” as being at the far end of a democratic continuum with a more interventionist style at the other end. To have seen "democracy” in this Galileian way would have meant classifying the problematic behaviour of the Charlie Chan group as being produced by an extreme form of “democratic leadership”. The problem is avoided by treating “democracy” as a binary concept, so that White's style ceases to be an instance of democratic leadership. Thus, Lewin protected the concept of “democracy" rhetorically, attributing the bad results to a form of non-democratic leadership.

\section{Ensuring the results make a good story}

The researchers performed a further act of rhetorical labelling to transform unfavourable results into favourable ones. In the mythology of the experiment, it is commonly asserted that the study demonstrated that autocratic groups were more aggressive than democratic ones. Statements to this effect can be found in social psychology textbooks, histories of psychology, organizational books and research reports: "in contrast to children in democratic groups, those in authoritarian groups expressed 30 times as much hostility” (Barone, Madddux and Snyder, 1997, p. 33); with the autocratic leaders “there was more aggression” (Brown, 2000, p. 94); “the authoritarian group was highly aggressive” (Hergenhahn and Henley, 2013, p.459); the researchers noted "high rates of hostility in the autocratically led 
groups” (Forsyth, 2009, p. 43); “the studies revealed that there was more aggression (about 30 times more) and more scapegoating in authoritarian led groups” (Macgowan and Wagner, 2005, p. 84).

These comments imply that mean measures of aggression were computed and compared across conditions. This is not a matter of later social psychologists interpreting Galileian, non-averaged data in a conventional Aristotelian style. Lewin et al (1939/1999) presented a table showing the average number of aggressive actions per meeting in the different leadership conditions (p. 237). Actually, they do not present a single score for “autocracy” but they give two autocratic scores. Had they offered a single score, the mean would have been 7.5, which would have been by far the lowest level of aggression for any of the three conditions: the mean for laissez-faire was 38 and for democracy 20. Instead, the authors divided the autocracy condition into the two most aggressive autocracy groups (whose average was 30) and the four least aggressive autocracy groups (average 2).

Having divided the autocratic groups into two categories, the authors then needed to label these categories. Unsurprisingly they called the first group "aggressive autocracies” and presented the scores of “Autocracy (aggressive reaction)”. Their name for the second group is revealing. Given that the groups were being split on the basis of their aggressiveness and given that no other groups in the whole experiment had lower average aggression levels than the four least aggressive autocratic groups, one might have expected that the latter would be called “non-aggressive autocracies” or even "peaceful autocracies”. However, that would have linked autocracy with a positively valued characteristic (non-aggressiveness). Instead, the researchers chose a negatively valued term- "apathetic”. The non-aggressive autocratic groups were classified as “apathetic autocracies” and its scores were described “Autocracy (apathetic reaction)”. 
Using the word "apathetic" solves the ideological problem of appearing to credit autocracy with a beneficial quality, while preserving the link between autocracy and the aggressive reaction. It was as if the non-aggressive autocratic groups were only nonaggressive because they were too apathetic to be aggressive. However, the so-called "apathetic" groups behaved in ways that make the description curious. When justifying their use of “apathetic”, Lewin et al (1939/1999) claimed that these autocratic groups “dull” and “lifeless” with little joking or smiling (p. 238). However, Lippitt and White (1958) reported that the democratic and the apathetic groups produced the highest rates of "work-minded conversation" (p. 502). They wrote that it was "interesting to find nearly as high a level of interpersonal friendliness in the authoritarian situations as in the democratic and laissez-faire situations” (p. 504).

White and Lippitt (1960) noted that many of the boys accepted autocratic leadership, seeing it as a necessary way of getting the job done; in these circumstances "the evidence of discontent among the boys was at a minimum” (p. 33) and accepting autocratic leadership could be combined with 'productive group discussion' (p. 34). The observers' notes of a group supposedly showing a "submissive attitude to autocracy” record: "the free, sociable, joking atmosphere disappears almost completely as hard work begins” and, when working hard, the boys were asking plenty of work-related questions (White and Lippitt, 1960, pp. 512; see also pp. 92f).

The term "apathetic" may solve the ideological problem but it does less than justice to the complexity of the children's behaviour. Perhaps it underestimates the extent to which accepting orders from adult authorities appeared ideologically "natural” to these schoolchildren. On the other hand, rhetorical simplicity is useful for creating mythology. Whereas some textbooks only mention the aggressive reactions of autocratic groups, others do say that autocratic groups were either aggressive or apathetic. Sometimes the apathy is 
exaggerated: Schulz-Hardt and Brodbeck (2008) write that in the apathetic groups there were “no instances of smiling or joking” (p 285), thereby upgrading Lewin et al’s already exaggerated "little smiling (and) joking” (1939/1999, p. 238). One textbook even omits the aggressive groups entirely: "When led in an autocratic style, the boys were lethargic and docile” (Kardas, 2013, p. 356). When it comes to affecting the judgements of others and creating a disciplinary orthodoxy, there may be few things as practical as a clear moral story.

\section{The Aristotelian legacy of the leadership studies}

We have seen briefly how later social psychologists have simplified the findings of the leadership studies. This is by no means unique as there are other examples of research findings being exaggerated and oversimplified (see critiques by Berkowitz, 1971; Billig, 2013; Cherry, 1995; Katzko, 2006). The leadership studies have been simplified into a moral fable, in which democracy was shown to be "good" and autocracy "bad”. It does not matter whether the levels of aggression are reported as being high or low under autocracy, the results are morally similar in that autocracy is found wanting. To use Lewin's terminology, these scientific stories are told using moral concepts that are Aristotelian, not Galileian.

Not all authors over-simplify the results to the point of distortion. Some mention the "bad" results of the democratic groups and the "good" ones of the autocratic groups but they tend to do using an interesting rhetoric that makes the ideological preferences all the more clear. When discussing the autocratic groups, the good points are typically mentioned first, followed by "but” (not "and”) or the writers will start with an "although" clause. Forsyth and Burnette (2005) comment that autocratic groups worked longer than democratic groups, “but hostility and aggression” were highest (p. 9). When Forsyth (2009) describes the study, he uses the "although" format: "Although these results argued in terms of the efficiency of an 
autocratic leadership style, the observers also noted that when the leader left the room for any length of time, the democratically led groups kept on working, whereas the boys in the autocratic groups stopped working” (pp. 42-3).

In these cases, and many others, the order of the propositions in the "but" and “although” statements could have been reversed - the writer could have said that "although the autocratic groups stopped working when the leader left the room, they had the more efficient rates of productivity”. Empirically both orders are permissible: scientific considerations, as opposed to ideological ones, do not preclude connecting the points with “and”, rather than "but” or "although”. However, the "good” points of the autocratic group typically come first, in order to be qualified, or discounted, by the "bad" points in the second part of the sentence. In terms of the overall story, the bad news that autocracy has good points must precede the good news that it has bad points, so that writers can overwhelm the former with the latter and give their sentences a happy ending. In this way, the little words "but" and “although” unobtrusively carry important ideological messages.

The textbook summaries use ordinary language, rather than technical terminology, to convey what happened in the leadership studies. Some of the original reports contained diagrams and formulae of field theory (Lewin et al, 1939/1999; Lippitt, 1940). These tended to be placed after the main findings had been presented, as if the authors were moving textually from Aristotelian to Galilean science. When Lewin summarised the findings in writings aimed at a non-technical audience, he would use the findings to tell a moral tale without technical terminology or topological diagrams. For instance, he suggested that Lippitt's studies "showed the beneficial effects which the democratic atmosphere has on the overt character of the member” (Lewin, 1944, p.196). Regarding the results from the second experiment, Lewin commented that the differences between democracy and laissez-faire 
"were very much in favour of democracy" (1948, p. 81). Here Lewin assumes that the dependent variables of the study assess moral qualities.

Lewin’s language was different when he summarised and discussed the findings in more technical writings, using topological representations of forces and spaces to describe what had happened (e.g., Lewin, 1946/1997 and 1947/1997). It was as if he were translating ordinary language into a specialist language with the translation adding little, if anything, conceptually original. Indeed, it is possible to detect the extent to which the topological representations were influenced by the ideological and moral assumptions of the more ordinary or Aristotelian interpretations.

Lewin (1947/1997) discussed a problem which Lewin et al (1939/1999) skirted around: why should some autocratic groups produce low levels of aggression and what distinguished them from the highly aggressive groups? Lewin answered the question by using complex topological formulae, representing the various forces in the situation. He suggested that the low outward aggression in "apathetic autocracy” did not indicate less aggression as a force in those groups. Instead in these groups there was greater autocratic control against outwardly displaying that aggression. Lewin expressed the point technically: "We are inclined to assume that the autocratic leadership form implies an additional force $\left(\mathrm{f}_{\mathrm{Gr}, \mathrm{c}}\right)$ which corresponds to the higher degree of authoritarian control and which in these situations has the direction against open aggression” (1947/1997, p. 316).

Two points can be noted. The first is that the topological explanation exemplifies the sort of psychological explanation which Gigerenzer (2010) criticizes as tautological. Lewin explains the absence of outward aggression in terms of an underlying force directed against outward aggression. How do we know there is such a force in apathetic autocracies? Because there is little outward aggression. The second point is that the explanation depends on the 
assumption that autocratic leadership implies a high degree of authoritarian control. One might say that this is a reasonable assumption in general. Certainly it reflected the extreme political autocracy from which Lewin had fortuitously escaped. However, this assumption scarcely reflected the reality of the autocracies in the leadership experiments. As has been mentioned, the authoritarian leaders possessed no punitive means to control the behaviour of the group members; and, in any case, any such control would have vitiated the validity of the experiment as an experiment.

It is as if the ideological meaning of the concept "autocracy" determines the interpretation of the experimental situation. Lewin (1947/1997) presented a formula to express the relationship between authoritarian control and outward aggression: $m+n\left(f_{\mathrm{PAGr}, \mathrm{c}}\right)$ $=\mathrm{p}>(\mathrm{m}+\mathrm{n}))$. Although exemplifying Lewin’s Galileian ambitions, the formula is essentially empty. Its basic meaning stems from the ordinary language, everyday meanings and ideological assumptions that create the situation which is to be formalised. In fact, the very formalization helps to protect those assumptions, since they become less visible and, thereby, less open to criticism. However, the formalizations can be peeled off, like an adhesive sticker on a parcel, without disturbing the contents of the parcel below. Recently, Burnes and Cooke (2013) have argued that Lewin's field theory could be profitably revived but without the mathematical topology and hodology. For Lewin, this would have been tantamount to abandoning the ideal of good theory and settling for the second rate. The problem is that the so-called good theory adds far less than it promises and it can be less, not more, meaningful than the ordinary descriptions on which it depends.

This also shows the unfortunate consequences of Lewin taking a very much reduced version of Cassirer's philosophy. Lewin, following the ideals of Galileian science, was looking for the forces and vectors that supposedly underlie human behaviour, thereby treating humans as Galileo treated physical objects moving in space. However, Cassirer’s emphasis 
on humans as symbol users suggests that psychologists and other social scientists should examine directly and in detail exactly how humans use language and symbols. Regarding the study of leadership styles, this would mean studying the ways that leaders, followers and researchers used language to produce the different group atmospheres. This would involve examining examples in their concrete particularity. As Lewin recognized, wider social meanings are realized within the details of particular instances and the particular case, when examined in depth, can hold the key to understanding broader patterns.

\section{Conclusions}

The preceding discussion points in a number of directions. The leadership studies bear out Lewin's preference for a different sort of method than has become orthodox within social psychology. This suggests that Lewin’s legacy to social psychology may be more complicated than is conventionally assumed. Critical social psychologists might benefit from seriously considering Lewin’s work. Certainly, discursive psychologists, who seek to discover general laws of social organization by qualitatively examining particular social interactions, may find that Lewin was not the sort of intellectual opponent that they might have assumed him to be. Moreover, critical psychologists might note that Lewin and Korsch (1939) included historical materialism amongst the types of concrete, qualitative analyses which they advocated (on the relations between Lewin and Korsch, see van Elteren, 1992; John et al, 1989). Certainly, critical psychologists have scarcely begun to take seriously those aspects of Lewin's work which the textbooks of social psychology routinely overlook (see Delouvée, Kalampalikis and Pétard, 2011, for an analysis of the ways that French textbooks depict Lewin). 
Another conclusion is that the leadership studies failed to live up to Lewin's own ideals of a Galileian science. The experimental situation, its results and interpretations were framed within binary, value-laden, ordinary concepts. It could not be otherwise once the researchers had decided to compare "democracy" with "autocracy”. The influence of those value-laden, highly ideological terms permeated all levels of the study, even when Lewin was using the supposedly neutral topological terms of field theory.

It would not be difficult to argue that Lewin's ideal of good theory contradicted his experimental practice because his conception of Galileian science sets unrealistic and inappropriate criteria for psychological sciences. Lewin’s contemporary, the Polish physician and microbiologist Ludwik Fleck, provided a much more realistic view of science. Drawing on his experience as a laboratory scientist, Fleck noted that medical science is not comprised of pure scientific concepts, but that it necessarily includes value-laden concepts such as “disease”, “pathology” and “illness” (Fleck, 1927/1986; Fleck, 1935/1979). Certainly, Fleck's view of science is closer to modern sociological thinking about science than is Lewin's adaptation of Cassirer's philosophy, whose image of science was based on physics rather than medical science (Cohen and Schnelle, 1986; Löwy, 1988 and 2000). Fleck’s analysis implies that social scientists, who wish to be scientific, need not feel obliged to remove ordinary language, value-laden concepts, such as “autocracy” and “democracy”, from their theorising, just as medical scientists do not need to avoid concepts such as "illness" and "health".

There is no evidence that Lewin was aware of Fleck’s work or, had he known of it, that he would have been influenced by it. Instead of speculating about Lewin's reactions to a very different image of science, we are left with a contradiction between the promise of harmony that his motto holds out and the example of his own work. In fact, the not so good sort of theory proved to be more practical, as Lewin used value-laden, ideological terms when 
addressing practitioners. Lewin has had a profound effect on the history of social and organizational psychology, but the textbooks, when citing his work, avoid the neutral technical formulae, which he spent so much care formulating, and instead they use ordinary, moral language.

Perhaps, this suggests a story of over-ambitious ideas coming down to earth in failure. Yet an alternative interpretation is possible, although this can only be sketched here and would need to be developed elsewhere. Maybe Lewin’s motto provides a vision of what might be possible in a society where the contradictions between theory and practice have already been economically and politically resolved. The concrete example of Lewin's studies, and of his own life, shows that he lived his later life in a contradictory society, where democracy was not straightforward but there were, to quote Lewin, deep "paradoxes of democracy” (Lewin, 1948, p. 50). No-one who had seen Hitler democratically voted to power could be naive about the practical fragility and imperfections of democratic ideals in modern society.

When there is a disjunction between a society's theory and practice - between its values and economic realities - then good theory may not be practical. Or at least, the famous motto might only work in theory, offering a theoretical cover for underlying contradictions (Weik, 2003). Lewin did not claim to be the author of the motto: he wrote that "a businessman once stated that 'there is nothing as practical as a good theory'” (Lewin, 1943/1999, p. 336). But, would a businessperson necessarily have the same view as a social critic about what constitutes a good theory; and would they agree upon the sorts of idea that they wish to see put into practice?

We can see from Lewin’s studies that not so good (Aristotelian) theory was more practical than good (Galileian) field theory. This apparent failure may be emblematic of 
current ideology and social conditions. Lewin, by pursuing the idea of rational theory so rigorously, might have exposed its limitations and thereby produced a telling message for our times. Today entrepreneurs are constantly marketing “good” theories about leadership, business practices and organizational dynamics. Theories are commercially valuable commodities, as the line between academia and business is no longer as clear as it might formerly have been imagined to be. Academics are urged by their employers to become entrepreneurial profit-makers (Billig, 2013; Slaughter and Rhoades, 2004). These are not the conditions under which an intellectually good theory will be the most practical - that is, the most profitable - theory. What can be marketed most easily are slogans dressed as good theories or theories reduced to brand names. Lewin’s failure to make his good theories practical can be seen as an emblematic achievement. By his own example, Lewin constructed the conditions for an invaluable insight: today, there is nothing as practical as a second rate theory. 
$\underline{\text { References }}$

Ash, M.G. (1998). Gestalt psychology in German culture, 1890-1967. Cambridge: Cambridge University Press.

Barone, D.F., Maddux, J.E. and Snyder, C.R. (1997). Social cognitive psychology. New York: Springer Science.

Berkowitz, L. (1971). Reporting an experiment: a case study in leveling, sharpening, and assimilation. Journal of Experimental Social Psychology, 7, 237-243.

Biber, D. and Conrad, S, (2009). Register, genre and style. Cambridge: Cambridge University Press.

Billig, M. (2008). The hidden roots of critical psychology. London: Sage.

Billig, M. (2011). Writing social psychology: fictional things and unpopulated texts. British Journal of Social Psychology, 50, 4-20.

Billig, M. (2013). Learn to write badly: how to succeed in the social sciences. Cambridge: Cambridge University Press.

Billig, M. and Marinho, C. (in press). Rhetoric and psychology: ending the dominance of nouns. In J. Martin, J. Sugarman and K. Slaney (Eds.), The Wiley handbook of theoretical and philosophical psychology. Oxford: John Wiley.

Brown, R. (2000). Group processes. Oxford: Blackwell.

Burnes, B. and Cooke, B. (2013). Kurt Lewin’s field theory: a review and re-evaluation.

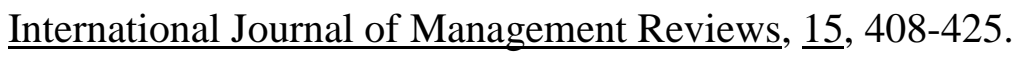


Carini, L. (1973). Ernst Cassirer’s psychology: II. The nature of thinking. Journal of the History of the Behavioral Sciences, $\underline{9}$, 266-269.

Cassirer. E. (1932/1951). The philosophy of the enlightenment. Princeton: Princeton University Press.

Cassirer, E. (1944/1962). An essay on man. New Haven: Yale University Press.

Cassirer, E. (1999). Two letters to Kurt Goldstein. Science in Context, 12, 661-667.

Cherry, F. (1995). The stubborn particularities of social psychology. London: Routledge.

Cohen, R.S. and Schnelle, T. (Eds.). (1986). Cognition and fact: materials on Ludwik Fleck. Dordrecht: D. Reidel.

Danziger, K. (1994). Constructing the subject. Cambridge: Cambridge University Press.

Delouvée, S., Kalampalikis, N. and Pétard, J-P. (2011). There is nothing so practical as a good...history: Kurt Lewin’s place in the historical chapters of French language social

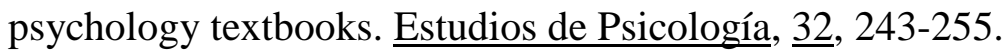

Edwards, D. and Mercer, N. (1987). Common knowledge. London: Methuen.

Fleck, L. (1927/1986). Some specific features of the medical way of thinking. In R.S. Cohen and T. Schnelle (Eds.), Cognition and fact: materials on Ludwik Fleck (pp. 39-46). Dordrecht: D. Reidel.

Fleck, L. (1935/1979). Genesis and development of a scientific fact. Chicago: University of Chicago Press.

Forsyth, D.R. (2009). Group dynamics, 5th edition. Wadsworth: Belmont, CA. 
Forsyth, D.R. and Burnette, J. L. (2005). The history of group research. In S. Wheelan (Ed.), The handbook of group research and practice (pp. 3-18). Sage: Thousand Oaks, Calif.

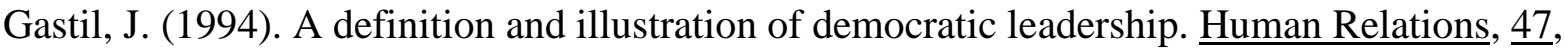
953-975.

Gibson, S. (2013). Milgram’s obedience experiments: a rhetorical analysis. British Journal of Social Psychology, 52, 290-309.

Gigerenzer, G. (2010). Personal reflections on “Theory and Psychology”. Theory \& Psychology, 20, 733-43.

Hammersley, M. (2010). Aristotelian or Galileian? On a puzzle about the philosophical sources of analytic induction, Journal for a Theory of Social Behaviour, 40 , 393-409.

Haslam, S.A. and Reicher, S. (2012). Tyranny: revisiting Zimbardo’s Stanford prison experiment. In J. R. Smith and S.A. Haslam (Eds.), Social psychology (pp. 126-141). London: Sage.

Hergenhahn, B.R. and Henley, T. B. (2013). An introduction to the history of psychology, seventh ed. Belmont, CA: Wadsworth.

Hyland, K. (2009). Academic discourse. London: Continuum.

John, M., Eckardt, G. and Hiebsch, H. (1989). Kurt Lewin’s early intentions (dedicated to his $100^{\text {th }}$ birthday). European Journal of Social Psychology, 19, 163-169.

Kardas, E.P. (2013). History of psychology: the making of a science. Belmont, CA: Wadsworth. 
Katzko, M.W. (2006). A study of the logic of empirical arguments in psychological research: “The automaticity of social behaviour” as a case study. Review of General Psychology, 10, 210-228.

Ledlow, G.R. and Coppola, M.N. (2011). Leadership for health professionals. London: Jones and Bartlett Learning.

Lerner, G.H. (1996). Finding “face” in the preference structures of talk-in-interaction. Social Psychology Quarterly, 59, 303-321.

Lewin, K. (1921/1999). Socializing the Taylor system. In M. Gold (Ed.), The complete social scientist: a Kurt Lewin reader (297-320). Washington, DC: American Psychological Association.

Lewin, K. (1931/1999). The conflict between Aristotelian and Galileian modes of thought in contemporary psychology. In M. Gold (Ed.), The complete social scientist: a Kurt Lewin reader (pp. 37-66). Washington, DC: American Psychological Association.

Lewin, K. (1936). Principles of topological psychology. New York: McGraw-Hill.

Lewin, K. (1938a). Will and needs. In W.D. Ellis (Ed.), A source book of gestalt psychology (pp. 283-299). London: Kegan Paul, French, Trubner.

Lewin, K. (1938b). The conceptual representation and the measurement of psychological forces. Durham, NC: Duke University Press.

Lewin, K. (1943/1999). Psychology and the process of group living. In M. Gold (Ed.), The complete social scientist: a Kurt Lewin reader (pp. 330-345). Washington, DC: American Psychological Association.

Lewin, K. (1944). Dynamics of group action. Educational Leadership, 1, 195-200. 
Lewin, K. (1944/1997). Constucts in field theory. In K. Lewin, Resolving social conflicts and Field theory in social science (pp. 191-199). Washington, DC: American Psychological Association.

Lewin, K. (1946/1997). Behaviour and development as a function of the total situation. In K. Lewin, Resolving social conflicts and Field theory in social science (pp. 336-381). Washington, DC: American Psychological Association.

Lewin, K. (1947/1997). Frontiers in group dynamics. In K. Lewin, Resolving social conflicts and Field theory in social science (pp. 301-336). Washington, DC: American Psychological Association.

Lewin, K. (1948). Resolving social conflicts. New York: Harper and Brothers.

Lewin, K. (1949/1999). Cassirer's philosophy of science and the social sciences. In M. Gold (Ed.), The complete social scientist: a Kurt Lewin reader (pp. 23-36). Washington, DC: American Psychological Association.

Lewin, K. and Korsch, K. (1939). Mathematical constructs in psychology and sociology. Erkenntnis, $\underline{8}$, 397-403.

Lewin, K. and Lippitt, R. (1938). An experimental approach to the study of autocracy and democracy: a preliminary study. Sociometry, $\underline{1}$, 292-300.

Lewin, K., Lippitt, R. and White, R.K. (1999/1939). Patterns of aggressive behaviour in experimentally created “social climates”. In M. Gold (Ed.), The complete social scientist: a Kurt Lewin reader (pp. 227-250). Washington, DC: American Psychological Association. 
Lewin, M. A. (1998). Kurt Lewin: his psychology and a daughter’s recollections. In G.A. Kimble and M. Wertheimer (Eds.), Portraits of Pioneers of Psychology, vol. III (pp. 105-118). Washington, DC: American Psychological Association.

Lippitt, R. (1940). An experimental study of the effect of democratic and authoritarian group atmospheres. University of Iowa Studies in Child Welfare, 16, 43-195.

Lippitt, R. and White, R.K. (1958). An experimental study of leadership and group life. In E.E. Maccoby, T.M. Newcomb and E.L. Hartley (Eds.), Readings in social psychology (pp. 496-511). New York: Holt Rinehart and Winston.

Löwy, I. (1988). Ludwik Fleck on the social construction of medical knowledge. Sociology of Health \& Illness, $\underline{10}, 133-155$.

Löwy, I. (2000). Medical acts and medical facts. Cracow: Polish Academy of Sciences.

Macgowan, M.J. and Wagner, E.F. (2005). Iatrogenic effects of group treatment with conduct and substance use problems: a review of the literature and the presentation of a model. Journal of Evidence-Based Social Work, 2005, 2, 79-90.

Manning, R., Levine, M. and Collins, A. (2007). The Kitty Genovese murder and the social psychology of helping. American Psychologist, $\underline{62}$, 555-562.

Marrow, A.J. (1969). The practical theorist: the life and work of Kurt Lewin. New York: Basic Books.

Nelson, D.L. and Quick, J. C. (2011). Organizational behaviour. Mason, OH: South-Western College Publishing.

Nelson, J.S, Megill, A. and McCloskey, D.N. (Eds) (1987). The rhetoric of the human sciences. Madison: University of Wisconsin Press. 
Perry, G. (2013). Behind the shock machine. London: Scribe.

Pomerantz, A. (1984). Agreeing and disagreeing with assessments: some features of preferred/dispreferred turn shapes. In J.M. Atkinson and J. Heritage (Eds.), $\underline{\text { Structures }}$ of social action (pp. 57-101). Cambridge: Cambridge University Press.

Reicher, S.D. and Haslam, S.A. (2006). Rethinking the psychology of tyranny: the BBC prison study. British Journal of Social Psychology, 45, 1-40.

Reicher, S.D. and Haslam, S.A. (2011). The shock of the old. The Psychologist, 24, 650-652.

Russell, N.J.C. (2011). Milgram’s obedience experiments: origins and early evolution. British Journal of Social Psychology, 50, 140-162.

Schulz-Hardt, S. and Brodbeck, F.C. (2008). Group performance and leadership. In M. Hewstone, W. Stroebe and K. Jonas (Eds.), Social psychology (pp. 264-284). Oxford: Blackwell.

Slaughter, S. and Rhoades, G. (2004). Academic capitalism and the new economy. Baltimore: John Hopkins University Press.

Smith, J.R. and Haslam, S.A. (Eds.). Social psychology: revisiting the classic studies. London: Sage.

Van Elteren, M. (1992). Karl Korsch and Lewinian social psychology: failure of a project. History of the Human Sciences, $\underline{5}$, 33-61.

Weick, K. E. (2003). Theory and practice in the real world. In H. Tsoukas and C. Knudsen (Eds.), The Oxford handbook of organization theory (pp. 453-474). Oxford: Oxford University Press. 
White , R.K. and Lippitt , R. (1960). Autocracy and democracy. New York: Harper and Brothers. 